\title{
The Model of Region Stable Development Provision
}

\author{
Gulmira Abisheva1, Aliya Zhumagulova², Zhanara Turalina², Amirzhan Turalin ${ }^{3}$, \\ Valeriya Kadochnikova ${ }^{4}$ \\ ${ }^{1}$ Department of "Tourism and Sport" at Kokshe Academy, Kokshetau City, the Republic of Kazakhstan \\ "2Economic Disciplines" Department at Kokshe Academy, Kokshetau City, the Republic of Kazakhstan \\ ${ }^{3}$ Social-Economic Department at Kokshe Academy, Kokshetau City, the Republic of Kazakhstan \\ "“Finance and Credit" Department at Kokshe Academy, Kokshetau City, the Republic of Kazakhstan \\ Email: gulya1363@mail.ru
}

Received 10 September 2014; revised 20 October 2014; accepted 3 November 2014

Copyright (C) 2014 by authors and Scientific Research Publishing Inc.

This work is licensed under the Creative Commons Attribution International License (CC BY).

http://creativecommons.org/licenses/by/4.0/

(c) (i) Open Access

\begin{abstract}
The paper presents the design of scientific-methodological fundamentals of the region economy stable development. While determining basic directions of region stable development and competitiveness provision, Akmolinskiy region in particular, economic specializations of development were singled out, complex research of social-economic situation was completed, revealing functioning conditions of strategic regional industrial structures and factors, influencing region stable development.
\end{abstract}

\section{Keywords}

\section{Region Stable Development, Competitiveness, Territory Sector Cluster, Tourism}

\section{Introduction}

National economy growth is directly proportional to entrepreneurship structures efficient functioning. In these conditions the issue of increasing competitiveness not only of an enterprise but the region as a whole has special significance. The President of the Republic of Kazakhstan in his message to Kazakhstan people has noted that "we have chosen the model of competitive economy with priority sectors, having economic potential of competitiveness increase, having laying foundation for the development of the system of Kazakhstan clusters” [1]. As international experience testifies such priority areas are agricultural sectors, the area of tourism and hospitality, etc. In modern conditions providing regional economy stable development and competitiveness contributes to 
fast modernization [2]. Complex analysis and organization-economic ways of development to provide regional economy stability and competitiveness on the basis of activity optimization of the Republic of Kazakhstan regional manufacturing structures are fundamental in the research.

Basic, strategic structures of the regions, whose manufacture was formed under the influence of historical, natural and economic factors, can form the conditions for fastest diversification of not only regional economy but also the whole Kazakhstan. Nowadays region economy stable development is a discrete process of constant character, the essence of which is in stable-balanced tempos of permanent growth and development of all regional economy on the whole for a long-time period. And regional competitiveness development is determined as synergetic effect of the alternative use of consolidated region potential [3]. In its turn, region stable development and competitiveness present the functioning of regulating mechanisms of strategic sectors and region enterprises long-term development with the possibility of regional potential development in future.

\section{Ease of Use}

Kazakhstan North region at present, Akmolinskiy region in particular, has economic specialization of industrial-agrarian type:

-Firstly, prevailing share of processing and agricultural industries in the structure of gross regional product;

-Secondly, basic sectors are tourism, hospitality, education;

-Thirdly, availability of high share of food industries; construction materials manufacture.

Thus, several development directions can be singled out in Akmolinskiy region economy-agricultural, tourism and hospitality, educational services [4].

Because of significant regional potential complex research of cluster development and cluster initiatives success of Akmolinskiy region was completed according to success criteria (Figure 1).

As it is seen from Figure 1, special attention should be given to the development of network partnership of cluster all participants, innovative technologies, human capital, physical infrastructure development.

In the conditions of economy diversification manufacture enterprises, sales finance, scientific-educational enterprises combine different areas of activity, industrial sectors, different regions and new type appears- - territory-sector cluster, combining all the enterprises according to production chain stages: raw materials extraction, processing, sales, post-sale service [5].
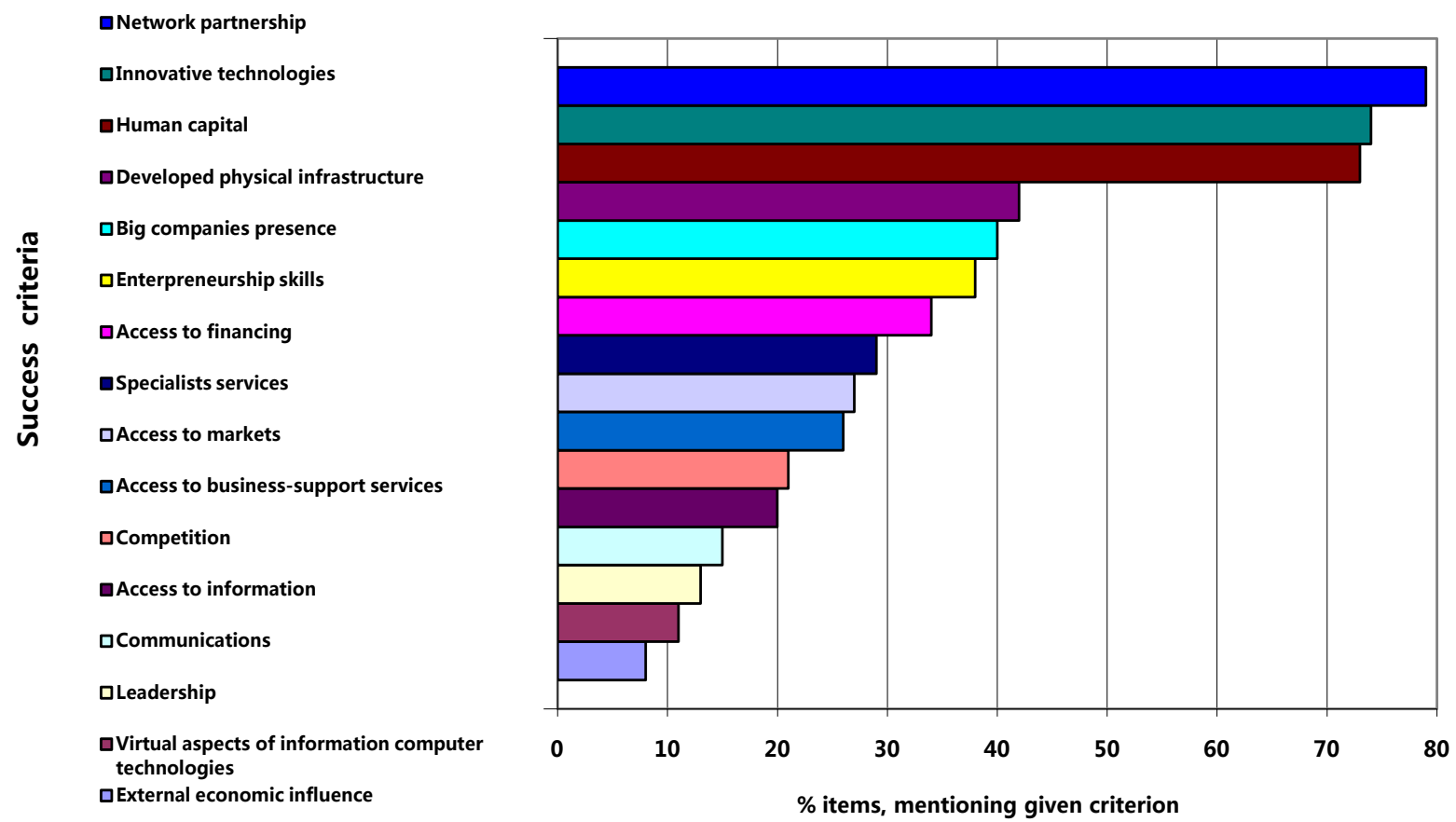

Figure 1. Success evaluation criteria of clusters development degree and cluster initiatives in Akmolinskiyy region. 
Thus cluster approach to provide region stable development and competitiveness contributes to different sectors companies' combination. It is carried out taking into account efficient use of internal resources with the aim of region economy modernization and region competitive advantages increase and provide stable development and competitiveness of the territory under research.

Cluster is an integrated system of big corporations, services and companies in complex policy of regional business structures to provide competitiveness taking into account interrelated sectors interests [6].

Integrated system of region stable development provisions includes the following clusters-suppliers:

1) mechanical engineering cluster includes transport enterprises (Kokshetau AVIA, railway transportation, bus fleets, LLC "Seinur" taxis, LLC "Vashe taxi”, Astanadorstroi, etc.) and power engineering "Kokshetau energoseti”;

2) construction cluster-hotel buildings construction and reconstruction, internal design, engineering network, etc. (construction company "Kulager", engineering construction company "Kokshetau”, KSTE+Kokshetaustroi);

3) cluster on woodwork and furniture manufacture-furnishing and aesthetic decoration of internal premises of the buildings, interior decorative design (LLC “Zhihaz Bars", "Furniture house”, furniture companies "Alladin", "Skazka", "Prestige");

4) crops-food-meat-dairy cluster-providing meat and dairy products to catering enterprises (LLC "Kokshetau bakery”, LLC “Kokshe nan”, private mini-bakeries, LLC "PCF Bolzhau”, "Kokshetau city dairy plant”, Kokshetau meat processing plant, etc.);

5) Light industry cluster—bed linen, tablecloth, uniform, etc. (Kokshetau sewing plant, knitted plant “Arman”, trade centers [7].

\section{Advantages of the Region}

The advantages of the region are natural, recreational (Shchuchinsko-Borovaya resort zone, Kotyrkolskaya recreational zone, Zerendinskaya recreational zone, Kogalzhynskay reserve area, Sandyktauskiy, Akkolskiy and Yereimentauskiy natural complexes):

-specialized objects—ethno cultural centers, tourist station, etc. (city stations of young tourists);

-recreational objects—reserves, forestry (State national natural parks "Burabay", "Kokshetau”) [8].

Evaluation of both quantitative and qualitative indexes was completed. While quantitative evaluation statistic indexes of the region development were used. Indexes variability is related to seasonality. Quantitative evaluation incudes development indicators of partnership relationship, innovations, human capital and competences at the enterprises included in the cluster.

Oral and written survey was conducted from March to May, 2014. About 230 respondents participated in the survey. 190 were questioned orally and 40 -in written form. The questionnaire involved 171 enterprises cluster participants.

To conduct the survey they were offered a number of questions, the answers to which allowed to determine: criteria of clusters and cluster initiatives development in Akmolinskiy region; determine basic indicators contributing to the receipt of economic results by all cluster participants (Figure 2).

Besides economic results, conclusions about the degree of cluster initiatives economic success conclusions can be made on the basis of the analysis of quantitative indexes for a number of years:

-expansion rates of tourism product joint production on the territory of cluster activity, out tourism tempos growth, including international tourist flows;

-market share change (ranging on the basis of market research.

In most cases big corporations operating in the market do not need them. Regional government authorities initiating cluster initiatives may be interested in them.

In this case strategic goals, connected with territory development specializing in agriculture and tourism are developed and become territory administration authorities. Either regional or state (private-state) administration should act as a leader in most clusters specially established corporation [9]. To succeed for cluster initiatives in such cases besides direct state investment and organization activity, supplementary stimulation and state support of competitiveness is necessary which is expressed in the system of economic privileges and state services (information, marketing services for small business).

Akmolinskiy region territory sector business environment evaluation is presented in Figure 3.

In this connection evaluating business environment of territory sector cluster of Akmolinskiy region it was found that cluster development creates the following advantages for various subjects: 


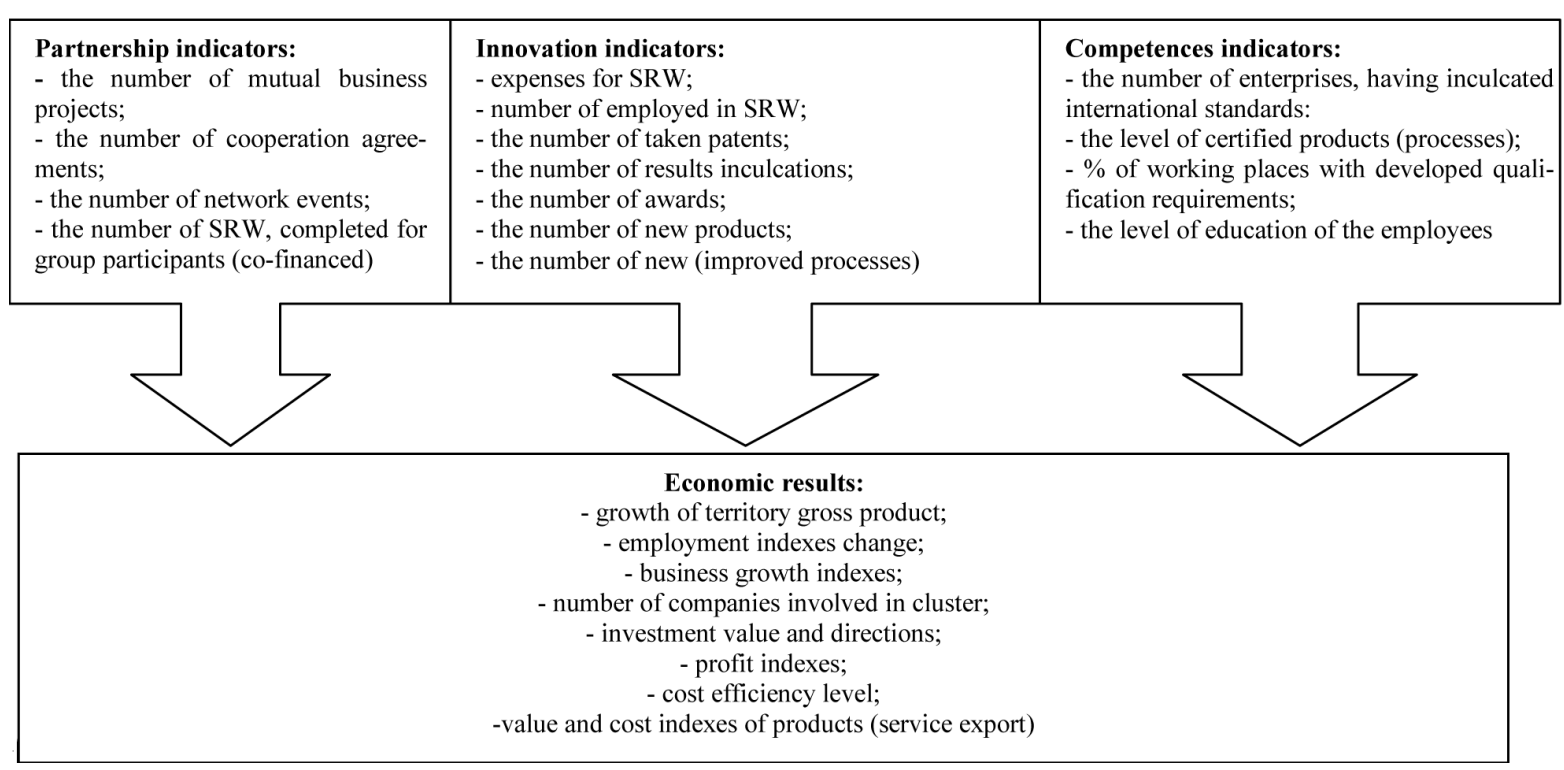

Figure 2. Basic indicators of Akmolinskiy region territory sector cluster.

\begin{tabular}{|c|c|c|}
\hline \multirow{2}{*}{$\begin{array}{c}\text { Non-commercial branch } \\
\text { Association of Akmolinskiy region tourism } \\
\text { and rest industry }\end{array}$} & \multirow{4}{*}{$\begin{array}{l}\text { State authorities } \\
\text { Akmolinskiy region tourism, physical } \\
\text { culture and sport administration; local } \\
\text { government; tax authorities; statistic au- } \\
\text { thorities }\end{array}$} & Banks (13 units) \\
\hline & & \multirow{2}{*}{$\begin{array}{c}\text { Hotels (212 units) } \\
\text { Catering objects (73 units) } \\
\text { Tourist companies, tourist agents (48) }\end{array}$} \\
\hline \multirow{2}{*}{$\begin{array}{c}\text { Educational institutions: } \\
\text {-higher (3); } \\
\text { - secondary professional (14), etc. }\end{array}$} & & \\
\hline & & $\mathrm{SA}$ «Employment center» \\
\hline $\begin{array}{l}\text { Companies providing marketing: printing } \\
\text { houses (18); television (1); publishing houses } \\
\text { (15) }\end{array}$ & \multirow[t]{2}{*}{$\begin{array}{c}\text { Business environment } \\
\text { territorial branch cluster } \\
\text { of Akmolinskiy region }\end{array}$} & \multirow{2}{*}{$\begin{array}{l}\text { Transport companies (96 units) } \\
\text { - air transportation (1 unit) } \\
\text { - railway transportation (1 unit); } \\
\text { - auto transportation ( } 94 \text { units); } \\
\text {-private entrepreneurs }\end{array}$} \\
\hline \multirow[t]{2}{*}{ Research structure (1) } & & \\
\hline & & \multirow{3}{*}{$\begin{array}{c}\text { Sale shops } \\
\text { Souvenir products ( } 43 \text { units) and goods } \\
\text { for hunting and fishing ( } 22 \text { units) }\end{array}$} \\
\hline Culture objects (16) & & \\
\hline Insurance companies( 15) & \multirow{2}{*}{$\begin{array}{l}\text { Controlling organizations } \\
\text { SSPE «Burabai»; ГHПП «Kokshetau»; } \\
\text { Korgalzhynskiy reserve }\end{array}$} & \\
\hline Other services companies (213) in IT area, & & $\begin{array}{c}\text { Food suppliers (965 units) Wholesale and } \\
\text { retail bases }\end{array}$ \\
\hline
\end{tabular}

Figure 3. Akmolinskiy region territory sector business environment evaluation.

For the state:

-stable economic growth;

-tax incoming into budget;

-convenient instrument for business interaction;

-unemployment decrease;

-foundation for territory economic development diversification and stress displacement from extraction in-dus-

tries to non-primary;

-depressive regions business activity growth;

-products export stimulation;

-state international status increase.

For business:

-market share increases;

-market infrastructure improves;

-production cost decreases;

-product competitiveness grows; 
-possibilities for entering international markets appear;

-cluster relationship subjects increase their initiatives and personal interest;

-innovations are inculcated and distributed;

-foundation for big, medium and small businesses cooperation is created.

For customers:

-product quality improves;

-product consumer properties improve;

-product (services) innovative properties improve;

-product (services) prices decrease.

\section{Conclusions}

Conducted research allows making the following conclusion and formulating practical recommendations contributing to North Kazakhstan stable development, Akmolinskiy region in particular:

1) Regions stable development provision in market conditions is a complicated process which is under the influence of various factors, connected and interrelated, significantly influencing territory organization. Taking into account all the factors stipulates the necessity of developing new approaches to solve manufacture, economic and social problems of the region and use of clusters on the basis of technological development and maximum effect receipt.

2) The following measures are recommended to provide region stable development:

-increase investment potential;

-priority regions financial support;

-tourism development encouragement;

-cluster initiatives usage;

-scientific provision and innovative technologies implementation;

-social infrastructure development;

-population level and quality of life improvement in the region.

\section{References}

[1] Nazarbayev, N.A. (2011) Message of the Republic of Kazakhstan President to Kazakhstan People.

[2] Ribov, M. (2003) Torusim Competitiveness Management. Sofiya.

[3] Ribov, M. (2005) Competitive Advantages in Tourism. Novaya Zvezda, Moscow.

[4] Nurgaliyeva, A.S., Ismailova, D.T. and Abisheva, G.O. (2013) Cluster Approach in Tourism Development.

[5] Ribov, M., Yaneva, Y., Velikova, et al. (2005) Competitive Strategy in Tourism. Sofiya. Trakiya.

[6] Abisheva, G.O. (2013) Providing Services Competitiveness in Hotel Business (on the Material of Akmolinskiy Region). Varna.

[7] Akmolinskiy Region Tourism Possibilities. http://visitkazakhstan.kz/

[8] http://www.turakmo.kz/

[9] Ribov, M. (2007) Search of Competitive Possibilities of Quantitative Tourist Product. 
Scientific Research Publishing (SCIRP) is one of the largest Open Access journal publishers. It is currently publishing more than 200 open access, online, peer-reviewed journals covering a wide range of academic disciplines. SCIRP serves the worldwide academic communities and contributes to the progress and application of science with its publication.

Other selected journals from SCIRP are listed as below. Submit your manuscript to us via either submit@scirp.org or Online Submission Portal.
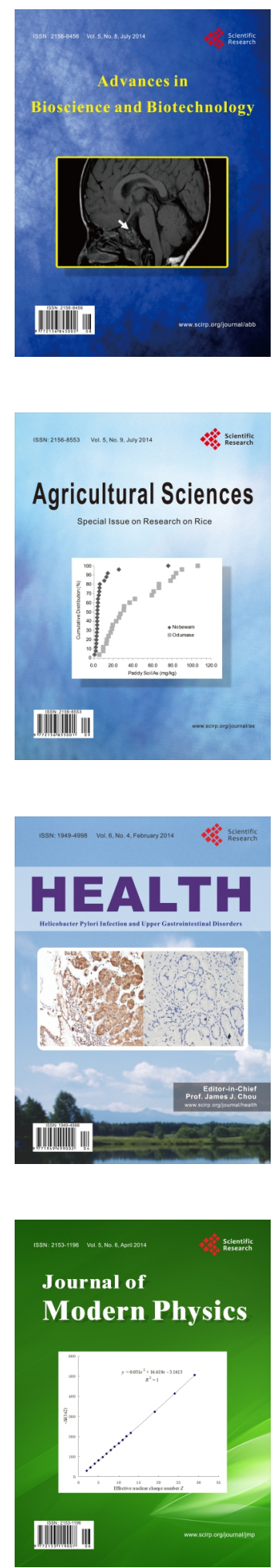
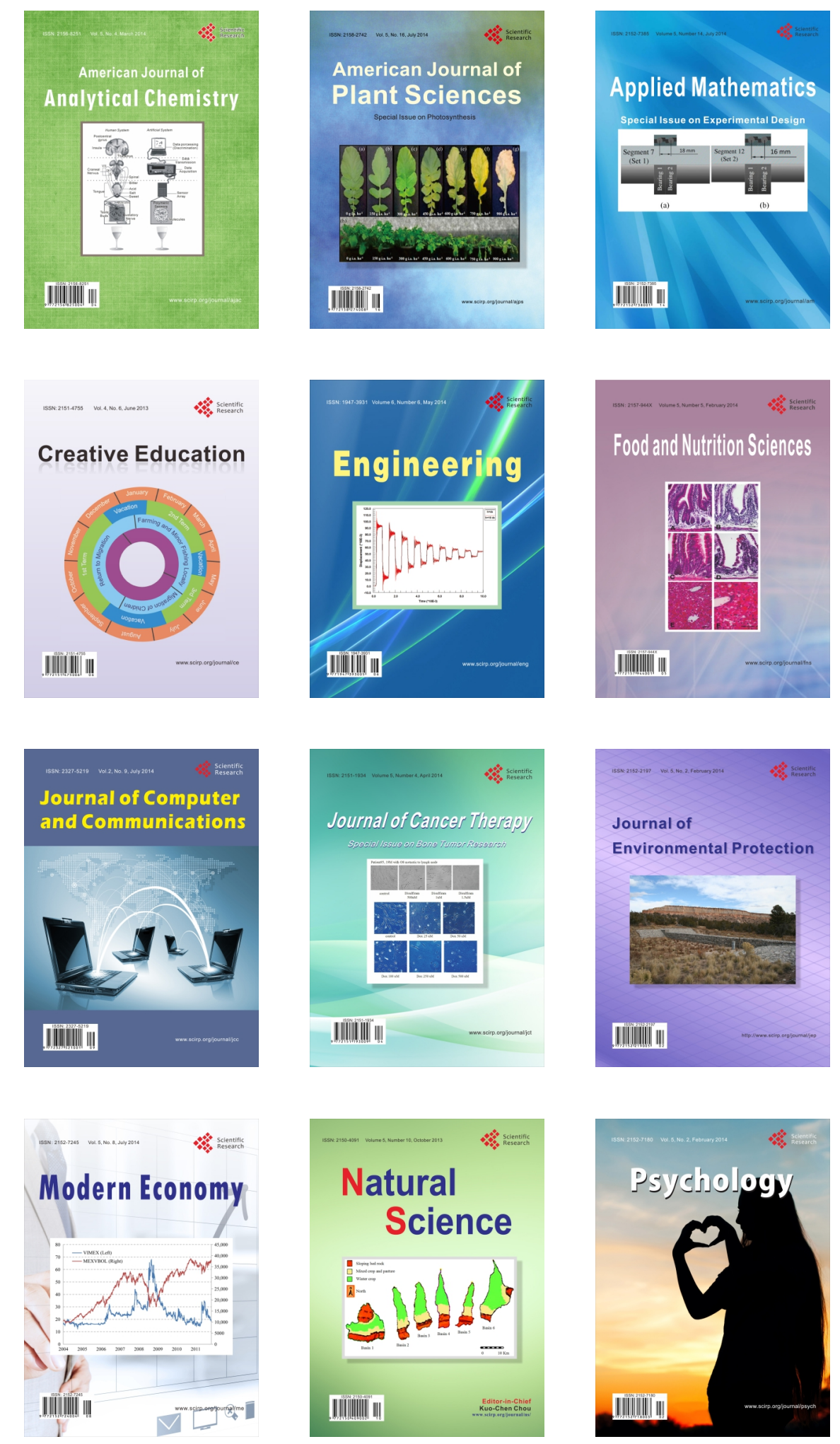